\title{
Suboptimal Size: Factors Preventing the Growth of Russian Small and Medium-Sized Enterprises
}

\author{
Victoria Golikova \\ Leading Research Fellow, Institute for Industrial and Market Studies, victoria@hse.ru
}

Boris Kuznetsov

Professor, Faculty of Economic Sciences; Leading Research Fellow, Institute for Industrial and Market Studies, bkuznetsov@hse.ru

National Research University Higher School of Economics, 20, Myasnitskaya str., Moscow 101000, Russian Federation.

\begin{abstract}
$\mathrm{T}$ The Russian manufacturing sector has an underdeveloped SME sector both in terms of employment and contributions to GDP in comparison with other economies, with evident signs of stagnation over the past few decades. However, little is known about the capacity of SME sector, i.e., the opportunities to grow and thus exploit the benefits reaped from economies of scale. This paper attempts to estimate the impact of internal and external factors on a firm's competitiveness in the context of optimal enterprise size.

The main conclusion is that that the satisfaction of Russian SME managers has been increasing due to factors such as the sufficient supply of qualified personnel, modern infrastructure, developed partnerships, the expansion

of the geographical scope of available markets and favorable institutional conditions for entrepreneurship. In contrast, serious constraints to SME growth in Russia discourage entrepreneurs and lead to poor decisions by managers such as exploiting shadow schemes, leaving the market or growth in the form of nominally independent firms under the informal "umbrella" of one owner. Formidable bureaucratic barriers and significant transactional costs increase the vulnerability of small businesses to administrative pressure. In order to survive and remain on the market, Russian companies have to adapt to the existing institutional environment, and must be larger compared to their counterparts in developed economies.
\end{abstract}

Keywords:

small and medium enterprises;

scale of business;

determinants of growth;

barriers to growth;

Russia.

Citation: Golikova V., Kuznetsov B. (2017) Suboptimal Size: Factors Preventing the Growth of Russian Small and Medium-Sized Enterprises. Foresight and STI Governance, vol. 11, no 3, pp. 83-93. DOI: 10.17323/25002597.2017.3.83.93 
I thas been empirically demonstrated that increasing the size of existing firms provides a major impetus for economic growth. For example, in [Rajan, Zingales, 1998] it was shown that for a sample of 43 countries, about two thirds of economic growth in terms of output was attributable to an increase in the size of firms, while the remaining one third came from the establishment of the new businesses. Therefore, over the past several decades, economic research has focused on the barriers impeding the growth of firms, which prevents the firms from reaching the "optimal" scale. On the other hand, this "optimal" scale ${ }^{1}$ may be very different depending on the industry and the specific sales market: the specifics of the produced goods, the size of this market, the structure of the market (concentration, network development), etc. Two different processes may lead to optimal scale: growth (mainly for young, small firms experimenting on the market) or on the contrary, downsizing, if a firm has become too large and difficult to manage.

The process of downsizing and restructuring Russias manufacturing sector took place in the early 1990-s during the transition to a market economy which continued into the mid-2000s and has been the focus of vast empirical research [Linz, Krueger, 1998; Djankov, 1999; Filatotchev et al., 2000; Estrin et al., 2001; Ahrend, 2006; Bhaumik, Estrin, 2007, among others]. During this period, the consequences of the search for "optimal" scale were to a large extent more often seen in the growth of young firms than in the downsizing of large former Soviet manufacturing giants.

Small business mangers consider optimal scale to be the difference between "actual and intended size" [Hermans et al., 2012, p. 12]. Such a multi-dimensional construct is the outcome of entrepreneurs' goals, the firm's strategic orientation, the evaluation of available resources to meet current market demand and benchmarking with competitors. In some sense, the views of optimal scale fall in line with the perception of a firm's success on the market, i.e., an indirect evaluation of the firm's current competitiveness and its sustainable position on the market. The managers of many firms are dissatisfied with their current scale of production [Weber et al., 2015]. On the one hand, this group includes quite successful firms that have not yet reached a desirable scale but intend to proceed in growing their business and exploit market opportunities. A strategic focus on high growth characterizes the best of entrepreneurial society [Autio et al., 2011]. On the other hand, directors' complaints about the inadequate scale of production may be an inherent feature of firms that wished to grow but failed in their competition with more productive companies. Due to such failure, they are likely to eventually leave the market.

In this paper, we will attempt to shed light on what determines the perceptions of scale of the managers of small and medium enterprises (SMEs), taking into account real performance and competitiveness.

Beside the internal, firm-specific features that may impact the opportunities for reaching an optimal size, we also consider the characteristics of the regional institutional environment that shapes the opportunities or constraints given to firm performance. In transitioning economies, the institutional environment often leads to an imbalance, facilitating the success of large firms while it restricts the opportunities for small and medium businesses. Moreover, empirical evidence from cross-country analyses calls attention to institutional deficiencies on the country level (weak intellectual property rights protection and corruption, etc.), which have a substantial negative impact on young firms aspirations for growth and development [Estrin et al., 2013]. In the case of Russia, the significant inter-regional diversity of the business environment should be taken into account as even neighboring regions can differ greatly regarding the conditions for doing business [EBRD, 2013; Bruno et al., 2008; Iwasaki et al., 2016].

\section{Determinants and patterns of SME growth: the Russian context}

A common feature of the countries with less successful transitions to market economies is the stagnation of their SME sector. In Russia, according to official statistics [Rosstat, 2014], the share of employment in this sector (25\%) and its contribution to GNP (21\%) are marginal and among the lowest compared to other countries. Since the market liberalization of the 1990s, entrepreneurship has failed to play a significant role in the Russian economy [Chepurenko, 2012], despite its potential to become one of the chief drivers of both economic growth and democracy in Russia [Richter, Schaffer, 1996]. The entrepreneurial dynamism, which is fundamental to innovation and growth according to the endogenous growth theory [Aghion, Howitt, 1997], simply has not yet been achieved in Russia. Small businesses remain too small and lack the sufficient scale to be truly competitive [Estrin et al., 2006; Peng, 2001; Puffer et al., 2010]. Furthermore, in 2012-2014 the share of players who had no growth aspirations, i.e., those did not plan to create jobs, increased significantly. ${ }^{2}$ This situation is confirmed by the conclusions of a mounting body of research on entrepreneurship in emerging economies [Manev, Manolova, 2010; Ojala, Isomaki, 2011]. However, in contrast to SMEs in developed economies, which face challenges mainly in achieving high rates of growth [Lee, 2014; Mason, Brown, 2013], the SMEs in transitioning economies, especially in Russia, struggle to grow at all [OECD, 2015; Welter, Smallbone, 2011; Smallbone et al., 2014]. Moreover, keeping in mind that this sector, especially as far as manufacturing is concerned, is heterogeneous and consists of quite a diverse population of firms - new entrepreneurial firms vs. former Soviet enterprises [Chepurenko, 2015] — we

\footnotetext{
${ }^{1}$ We consider the optimal scale a firm's competitive position in terms of its size and cost levels [Bennet, Levinthal, 2017]. Optimal scale is a consequence of a firm's growth.

${ }^{2}$ http://www.gemconsortium.org/country-profile/104
} 
might expect quite different patterns in their development as regards growth, downsizing or stagnation. This means that the Russian SME sector is not quite synonymous with the entrepreneurial sector and this point is important in understanding perceptions concerning the scale of production.

One must distinguish between the initial and mature stages of the life cycles of SMEs. Acs and Audretch [Acs, Audretch, 2001] noted that the opportunity to grow and survive in post-entry period is determined by the difference between the minimum efficient size (MES) and the actual size of the firm. This is the main motivation for growth among the entrants. Empirical evidence from developed countries suggest that firms follow an "up-or-out" dynamic where small firms are more likely to go bankrupt than larger firms, but in the case of success, the chances for growth rise [Bartelsman et al., 2013; Navaretti et al., 2014; Geurts, van Biesebroeck, 2016, etc.]. In general, the average size of a firm will double after 5-10 years on the market, but only fifty percent of entrants will survive [Geurts, van Biesebroeck, 2016]. This is how the mechanism of allocative efficiency works in developed market economies. A similar trend was found in the developing economies of Eastern Europe where there was very low or even negative allocative efficiency at the beginning of the transition period and only later did it improve significantly [Bartelsman et al., 2013].

In contrast, there are still no clear indications of improving allocative efficiency in Russia. The specific problem facing Russia's economy is the extreme volatility of the economy. In periods of long and deep slumps, new and efficient companies are given fewer chances to survive than older firms that face less intense competition. So, they leave the market before they achieve the minimum efficient size. The inefficient incumbents "hold onto resources that more efficient firms could use if they were freed up" [González et al., 2013]. In the Russian case, it is more likely to find these "holders of resources" among large former Soviet manufacturing firms that can be quite happy about their scale of production though they are less productive and by remaining on the market they continue to constrain the Schumpeterian process of "creative destruction" 3 . As Hsieh and Klenow [Hsieh, Klenow, 2009] recently documented, in less developed economies, production factors are often concentrated within unproductive firms while new entrants suffer from limited access to foreign resources, capital, and technologies, while at the same time they face poor infrastructure and political instability. As a result, small firms' growth is slowed, medium enterprises are practically absent (the phenomenon of the "missing middle") and the few large firms enjoy preferential treatment, dominate policies, block competitors' access to the market, and have special relationships with the government and banks [Tybout, 2000].

"Learning-by-doing" models, in our opinion, most fittingly illustrate firms' growth behavior and the perception of adequate scale. This approach was initially considered within the framework of the concepts of passive learning [Jovanovic, 1982] and active learning [Ericson, Pakes, 1995; Pakes, Ericson, 1998]. In the aforementioned works, the heterogeneity in growth among industrial producers was evaluated using a single index based on a costs/productivity ratio. ${ }^{4}$

Subsequently, in research on this issue, the impact of technological progress and specific factors of profitability on the balance of supply and demand began to be taken into consideration. Each aspect could follow separate and occasionally independent stochastic processes [Foster et al., 2012]. Supply side factors were not found to be primarily responsible for firms' heterogeneity in terms of growth and survival in developed economies. In less developed economies, financial constraints due to insufficient internal savings and strong discrimination against small firms on credit markets impede growth [Song et al., 2011] and should not be ignored. The same comment is relevant to capital adjustment costs that are important in some contexts [Foster et al., 2012] and to human capital resources [Ployhart, Moliterno, 2011]. We suppose that in developing economies such as Russia, supply-side determinants of growth, which are reflected in SME directors' perceptions of optimal scale, must be considered. One should consider such indicators as a firm's profitability, which gives one an idea of a firm's internal savings for growth, its access to external financial resources, the availability of qualified personnel and the quality of its fixed assets (equipment).

According to data from the U.S. Census of Manufacturers, which has been carried out since 1977 and contains 17,000 plant-year observations on production in physical units (and thus makes it possible to observe plants' output quantities and prices, not only total revenue) demonstrated that even on commoditylike product markets, the patterns of growth do not simply reflect productivity gaps, but rather show the differences in supply-side fundamentals [Foster et al., 2012]. This means that new businesses must lower prices today in the hope of stimulating demand for tomorrow. Calculations based on price elasticity using a model with depreciation show that a ten percent price cut will increase current sales by about 18 percent and current profit by eight percent. Accordingly, this increase in revenue will lead to a shift in the firm's demand

\footnotetext{
3 The reasons of their not leaving the market is beyond the scope of this paper.

${ }^{4}$ Jovanovic's passive learning [Jovanovic, 1982] explains the behavior of new firms that do not enter the market at an optimal size and gradually determine the level of their efficiency level by working on the market. Observations on realized profitability lead to one reconsidering their beliefs about their productivity and in accordance with said new beliefs, a firm either expands or contracts. For mature firms in the manufacturing sector, the concept of active learning [Pakes, Erikson, 1998] is most appropriate [Geurts, van Biesebroeck, 2016]. Manufacturing is characterized by higher entry costs and scale, and higher minimum efficient scale that those found in other industries [Geurts, van Biesebroeck, 2016]. Manufacturing firms at the moment of entry are more likely to have already gained knowledge about their efficiency and an idea of optimal scale of production. The model of active learning suggests that evaluating its own technology and market environment only high-productivity firms may find it profitable to make investments that will encourage future growth.
} 
over the following year by about four percent [Foster et al., 2012]. Thus, investments in relationship-specific capital - the increase of one's customer base, building a reputation among customers and strategic partners that could provide tacit knowledge [Street, Cameron, 2007; Hessels, Parker, 2013; Mohr et al., 2014; Rice et al., 2012], improving the quality of post-production services, etc. — are highly rewarded and help one achieve an optimal scale of production in the long run, but not immediately.

Most recent research draws attention to demand-side factors as entrepreneurs usually mention insufficient demand as one of key obstacles to their firms' growth [OPORA, 2016]. We capture demand-side factors by analyzing the features of a firm's markets and evaluating GRP per capita in the firm's local markets given that SMEs sell all or a substantial share of production on local markets. We assessed investments in relationshipspecific capital that might facilitate demand based upon the availability of strategic partnerships with local and foreign firms that were established two to three years prior to the conduct of the survey.

The aforementioned determinants, both demand and supply side, are relevant for all countries, however, in transitioning economies, their impact on growth and sometimes the vector of a business's development is determined by the features of the institutional environment. The body of empirical research on SME performance in developing economies found a robust relationship between firm performance and the quality of institutions [Aidis et al., 2008; Molz et al., 2009; Blagojevic, Damijan, 2013; Sharafutdinova, Kisunko, 2014; Yukhanaev et al., 2015; Volchek et al., 2013a,b; Wang, You, 2012; Krasniki, Desai, 2016; Welter, Smallbone, 2011]. However, the mechanism behind their interactions remains poorly studied. An analysis of institutions is of paramount importance in the study of emerging economies where formal institutions are often ineffective arbiters for competitive markets and structurally unable to foster a business-friendly environment [Hoskisson et al., 2011]. Economies that did not manage to develop according to the Western model must operate under an alternative informal institutional network [Smallbone, Welter, 2010], which is prone to rent-seeking, shadow schemes and similarly, tends to incentivize sub-optimal behavior among firms [Golikova, Ermilova, 2006; Sharafutdinova, Kisunko, 2014]. As a result, a discussion of a firm's aspirations for growth, scale of production and performance in transitioning economies without recourse to a study of institutional issues is liable to be incomplete [Aidis et al., 2008; Aidis, 2015; Welter, Smallbone, 2011; Smallbone et al., 2014; Krasniki, Desai, 2016; Wang, You, 2012]. Moreover, an institution-based study has become the main theoretical framework for business research on emerging economies and researchers tend to explore the interplay of formal and informal institutions at multiple levels of analysis [Thorsten et al., 2005; Meyer, Peng, 2005, 2016; Estrin et al., 2013]. In our research, we are mostly interested how the institutional environment, assessed by the level of regional corruption, determines the perceptions of firms concerning optimal scale. This will be studied with account of the different age cohorts, i.e., a consideration of the life cycle of the studied businesses with special attention given to new firms [Acs, Armington, 2004].

The determinants of firm growth described above, such as supply- and demand-side factors, are still valid for firms operating within emerging economies. However, their effectiveness and the direction of their effect is often determined by the idiosyncrasies of the institutional environment [Marcelin, Mathur, 2015; Cuaresma et al., 2013; Volchek et al., 2013a,b; Molz et al., 2009; Dallago, 2000; Blagojevic, Damijan, 2013; Welter, Smallbone, 2011; Yukhanaev et al., 2015].

\section{Perceptions of optimal scale: European vs. Russian firms}

One of the possible approaches to select firms with sub-optimal sizes is to ask the firms' CEOs. It should be stressed that this indicator is more about the perceptions than about the "objective" difference between the desired and actual scale of their firm. Such perceptions may simply be a sign of general dissatisfaction with firm performance rather than a true assessment the inadequacy of scale per se. Nevertheless, this selfassessment allows us to pick up on firms that for some reason or another have not yet achieved or sustained a "comfortable" scale of activity. Either they are growing too slowly or are downsizing despite the initial intentions of the entrepreneurs. One must try to understand the external and internal factors affecting directors' attitudes about the unattainability of a desirable scale of production.

This approach was used in the EU-funded survey, European Firms in a Global Economy: Internal Policies for External Competitiveness (EFIGE). ${ }^{5}$ During this project, more than 14,000 manufacturing firms in seven EU countries were asked the following question: "Compared to your competitors, do you think that your firm's scale of production is adequate?" As the survey was conducted in 2010 and covered the period of the recent 2007-2009 crisis, when many firms had to downsize their business, it might be expected that firms, especially small ones, would more often complain about the insufficient scale of operations. Furthermore, there should be a great heterogeneity in their assessments across countries, industries, and size groups. However, contrary to expectations, the share of firms' owners/managers complaining about the scale of business was not very large in European countries (about 13\%) and the differences between countries, industries and size groups were not very significant ${ }^{6}$.

\footnotetext{
${ }^{5}$ Details on http://bruegel.org/efige/.

6 The relative outliers were Hungary (with a 22\% share of "complainers") and Austria (with only $8 \%$ ), which may have been due to the relatively small size of the economies and the relatively small sample sizes for those countries.
} 


\section{Figure 1. Dissatisfaction with the actual scale of operations: the share of firms by size groups} in seven EU countries and Russia

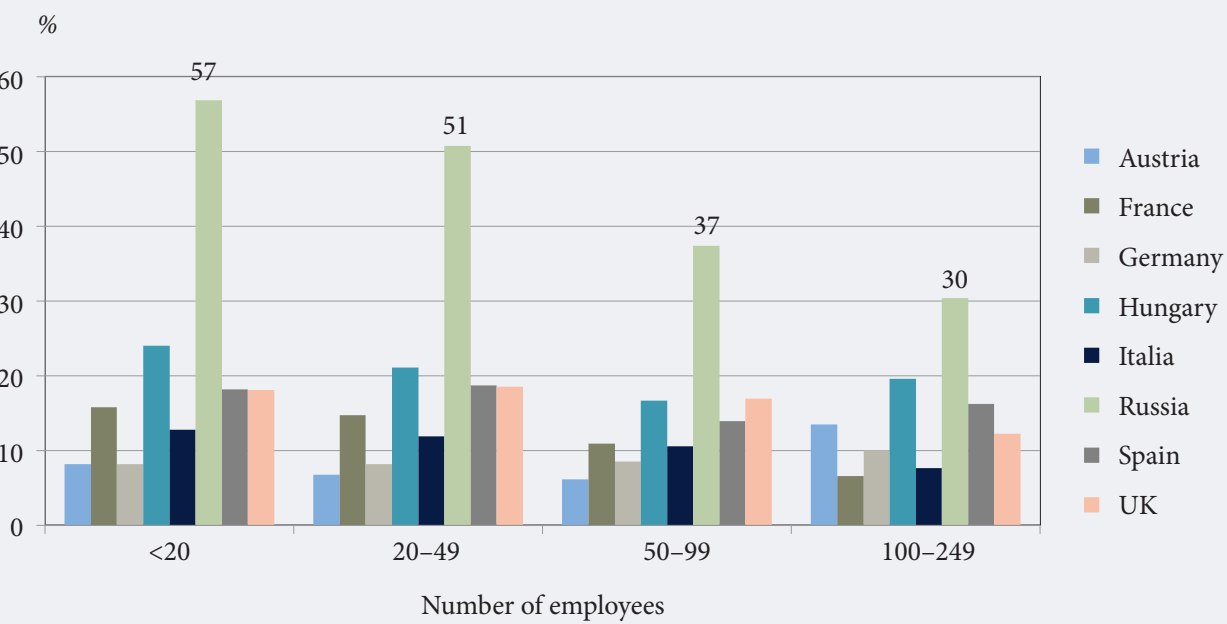

Source: compiled by the authors using EFIGE (2010) and RuFIGE (2014) survey data.

Five years later, a similar survey was conducted for Russian manufacturing firms ${ }^{7}$ with the same question included in the survey. This survey revealed a very different picture. The average share of Russian manufacturing firms dissatisfied with their scale of production was found to be $46 \%$ for the total sample and about $50 \%$ for SMEs (firms with fewer than 250 employees). In addition, there was great variety across size groups and industries: $32 \%$ of the firms with 100-250 employees complained about their scale of production, while for the group of the smallest firms (10-20 employees), the share of dissatisfied firms was much higher - 57\% (Figure 1). So, every second Russian manufacturing SME considers its scale of production insufficient for successfully competing on the market.

These results cannot be explained by differences in the actual size of firms in the Russian and EU manufacturing sectors in terms of employment. The mean number of employees at manufacturing SMEs in the 10-250 employee size group (weighted to control for sampling bias ${ }^{8}$ ) of all seven EU countries is 37.8 employees (varying from 42.7 in Germany to 32.4 in Italy) versus 42.4 employees in the Russian manufacturing SME sector. Nor can the results be explained by the age of firms (newly founded firms are expected to be smaller as they are still growing and have not yet reached their optimal scale): the share of firms under four years in the Russian and EU samples is approximately the same: about 7-9\%. According to our estimates, the huge gap between European and Russian firms is in median sales (2.584 million euros against 433,100 euros, respectively). This means that the scale of production of Russian SMEs is only $16.8 \%$ of their European counterparts.

\section{Data and Methodology}

The database we use was drawn from the RuFIGE (Russian Firms in the Global Economy) survey of 1,950 Russian manufacturing firms with at least 10 employees. The survey was conducted by GFK-Russia survey company in June-November 2014. The random structured sample was constructed in order to be representative in terms of distribution by industry and firm size. Face-to-face interviews with company directors using a semi-structured questionnaire were conducted in 60 Russian regions, though the sample was not representative by Russian regions. For this paper, we use a sub-sample of SME firms with 10249 employees (1,380 observations). The survey includes questions about the form of ownership, investments, innovation activity, other factors of production as well as assessments of the investment climate and the institutional environment. Another part of the original survey data consists of regional economic indicators from the official statistics and regional institutional indicators of INDEM. ${ }^{9}$

Using the described instruments, we evaluate the impact of different firm-specific features and regionalspecific institutional indicators on the probability of a firm being satisfied with the scale of operations while

\footnotetext{
The data used in this work was collected as a part of the research project "Russian Firms in a Global Environment" implemented within a framework of the Basic Research Program at the National Research University Higher School of Economics (HSE) in 2014-2015. For more details see: https://iims.hse.ru/rusfirms.

8 The weights were calculated in line with [Navaretti et al., 2010].

9 INDEM ("Information Science for Democracy") is a Russian NGO collecting data on various issues concerning corruption, justice, governance, political and regional issues, etc.
} 
controlling for industry and regional specifics and the individual characteristics of the firm. We assume that the answer to the question "Is the scale of your production adequate?" correlates with the latent variable of optimal ("adequate") scale. That is, if a firm complains about its scale of operations, there are some internal and/or external factors preventing it from either maintaining a reliable scale of production or from growing to an adequate size. Based on the reviewed literature, we are trying to verify three hypotheses:

H1: The failure to achieve an optimal scale of production may be due to negative supply side factors, i.e., a lack of resources, which leads to the relatively low quality of inputs and/or outputs.

The hypothesis is in line with the reviewed literature [Hermans et al., 2012] as well as with empirical evidence about the Russian manufacturing sector in general and the development of SMEs in particular: lack of access to and the high price of external finance, the deficit (and high cost) of qualified personnel and modern technologies, the relatively low levels of networking, communication and cooperation, etc.

H2: Firms have a sub-optimal scale due to unfavorable demand side factors, in particular, due to high transaction costs that create barriers impeding SMEs from entering new markets (in other regions and/or countries) and preventing firms from reaching an adequate size of operations.

The second hypothesis is based on the theory of heterogeneous firms [Melitz, 2003] and presumes that the higher the barriers of entry, the more important is companies' self-selection. In the case of Russia, such transaction costs include undeveloped market infrastructure including high transportation costs as well as the customs barriers for export operations. In other words, a firm is prevented from growing to the desired size because the market is not large enough.

H3: The firm is constrained in its growth or kept from maintaining optimal scale due to the unfavorable institutional environment in the region of operations. These constraints are more significant for relatively younger firms.

The hypothesis is based on empirical evidence concerning the significant differentiation of the institutional climate in the Russian regions [EBRD, 2013]. Those differences, first of all, include administrative pressure from the authorities, including the level of corruption. As demonstrated in the literature, an unfavorable business climate negatively impacts the process of creating SMEs, presumably by hindering firm growth.

\section{Model and Results}

In our research we used a simple probit model, where the satisfaction or dissatisfaction with the scale of business is a dependent dummy variable and different firm-specific, industry/market-specific, regionspecific factors are explanatory variables. The general formula is:

$$
\begin{aligned}
& \operatorname{Pr}\left(\text { Scale }_{i}\right)=\alpha 1\left(\text { Firm-performance indicators }_{i}\right)+\alpha 2\left(\text { Market-specific }_{i}\right)+\alpha 3(\text { Institutional indicators })+ \\
& +\alpha 4(\text { Regional_controls })+\alpha 5 \text { (Sectoral_controls })+\varepsilon
\end{aligned}
$$

The variables used it the model are described in the Table 1. The descriptive statistics for the total sample and for the two groups of SMEs (satisfied and unsatisfied with the scale of business) are reported in Table 2. We report the three models below. Model 1 includes Firm-specific indicators related, first, to the supply side limitations such as low sales margins, a lack of the qualified workers, restricted access to external finance and poor quality of equipment, which is measured by the share of equipment older than 10 years. Demand side restrictions are also taken into account. The proxy is a variable showing the scope of markets where a firm is selling its product - regional market only (base category), to other regions of Russia, or to other countries. The assessment indicators are controlled for age groups (as described above), the size of the firm (the logarithm of the number of employees) and for the type of sector (Pavitt classification). In Model 2, regional variables were added: Gross Regional Product per Capita and the Corruption Index (as a proxy for the regional quality of the institutional environment). In the last specification (Model 3), we included the cross-sectional data for age groups and the corruption index to check the hypothesis about how the impact of institutions depends upon the age of a firm. The errors are clustered by regions and we use weights calculated by using the general population structure to adjust for sample bias toward certain industries and size groups. The results for the three models are provided in Table 3.

We tested the results for robustness by including different additional factors such the position, age, and sex of the respondent, the family status of firm (whether or not the firm is owned by a family) ${ }^{10}$. All the results proved to be robust.

\section{Discussion}

We shall begin the discussion with our findings on the first hypothesis related to the supply side deficiencies. As we expected, the complaints about the insufficient scale of a business are strongly tied to low profitability.

\footnotetext{
${ }^{10}$ Besides for the check for robustness, such variables were used in the empirical research on the entrepreneurship to control for "the intentions" of firms [Kolvereid, 1992; Stenholm, Toivonen, 2009; Estrin et al., 2013].
} 


\section{Table 1. Variables of the probit model}

\begin{tabular}{|c|c|}
\hline Variable code & Description \\
\hline Scale & $\begin{array}{l}\text { Dependent dummy variable, a dummy equals } 1 \text { if a respondent says that the scale of business is adequate in } \\
\text { comparison with other competitors }\end{array}$ \\
\hline \multicolumn{2}{|r|}{ Firm-level characteristics } \\
\hline Deficit_qual_workers & $\begin{array}{l}\text { A dummy variable based on firms reporting a deficit of qualified workers as "a very serious problem": } 1 \text { - the } \\
\text { problem is very serious, } 0 \text { - it is not serious }\end{array}$ \\
\hline Margin & A dummy variable, which equals 1 if sales margin is above $2 \%, 0-$ if it is lower than $2 \%$ \\
\hline External_finance & A dummy variable, which equals 1 if a firm used banking loans in the period 2011-2013, 0 - if otherwise \\
\hline Old_equipment_share & A quantitative indicator of the share of production equipment 10 years or older \\
\hline Age_of_firm & $\begin{array}{l}\text { Categorical variable: } 1 \text { - firms established after the } 2008 \text { crisis }(2009-2013) ; 2 \text { - firms founded during the period } \\
\text { of economic growth of } 1999-2008 ; 3 \text { - firms established during the transition crisis of 1992-1998; } 4 \text { - firms } \\
\text { established during the Soviet period (before 1992) }\end{array}$ \\
\hline \multicolumn{2}{|r|}{ Markets indicators } \\
\hline Marketsize & $\begin{array}{l}\text { The categorical variable equals } 1 \text { if a firm is selling its product only in the region where it is located, } 2 \text { if a firm is } \\
\text { operating in other Russian regions as well, and } 3-\text { if a firm is exporting its goods }\end{array}$ \\
\hline Partnerships & $\begin{array}{l}\text { A dummy variable, which equals } 1 \text { if a firm reports having strategic partnerships with Russian partners } \\
\text { established at least } 3 \text { years prior to the interview and } 0 \text { if otherwise }\end{array}$ \\
\hline \multicolumn{2}{|r|}{ Regional indicators } \\
\hline$G R P \_p c$ & Logarithm of Gross Regional Product per capita in 2011 (rubles) \\
\hline Corruption_index & $\begin{array}{l}\text { The aggregated indicator of "every-day corruption" in a firm's home region. The indicator is calculated by the } \\
\text { INDEM Foundation for every Russian region [MED, FOM, 2011]. We use the latest available data (2010). It is } \\
\text { a quantitative indicator varying from } 0 \text { to } 1\end{array}$ \\
\hline \multicolumn{2}{|r|}{ Controls } \\
\hline LogEmpl & Logarithm of the number of employees in 2013 \\
\hline Sector & $\begin{array}{l}\text { Categorical variable for four sectors using the Pavitt taxonomy: } 1 \text { - Supplier-dominated; } 2 \text { - Scale-intensive; } \\
3 \text { - Specialized suppliers; } 4 \text { - Science-based (for further reference see [Pavitt, 1984]). }\end{array}$ \\
\hline
\end{tabular}

We do understand, however, that we may have a problem with reverse causality here. Insufficient profits do constrain growth, but the inadequate scale of business also may be the reason behind low profits. Another proxy for supply-side limitations is the share of old equipment. The coefficients were always negative and strongly significant. This result is more reliable in terms of the reverse causality problem. It demonstrates that firms with relatively outdated equipment may face higher costs of production and/or are incapable of providing goods of a certain quality. The shortage of a qualified workforce, another measure of the supply side deficiencies, also negatively impacts satisfaction with one's scale of business.

As demonstrated in the literature [Smallbone, Welter, 2010], active outsourcing and networking can compensate for the small size of a firm. In other words, a firm can be smaller but just as efficient if it can obtain certain supplies and services from the market. The networking capacities, which we measure by the existence of strategic partnerships, are strongly and positively correlated with the adequacy of firm scale. The existence of established partnerships increases the probability of a firm being happy with its scale of business by more than $14 \%$.

\section{Table 2. Descriptive statistics}

\begin{tabular}{|c|c|c|c|}
\hline Variable & Scale_sufficient & Scale_insufficient & Total \\
\hline Deficit_qual_workers & $18.9 \%$ & $25.1 \%$ & $20.1 \%$ \\
\hline Margin_low & $9.6 \%$ & $17.1 \%$ & $13.3 \%$ \\
\hline External_finance & $38.5 \%$ & $46.7 \%$ & $41.1 \%$ \\
\hline Old_equipment & $23.9(28.8)$ & $31.2(35.4)$ & $27.00(32.0)$ \\
\hline Marketsize1 (regional) & 54.1 & 43.8 & 49.1 \\
\hline Marketsize2 (interregional) & $43.8(36.0)$ & $39.7(37.7)$ & $41.4(36.7)$ \\
\hline Marketsize3 (exporters) & $59.4 \%$ & $68.3 \%$ & $62.5 \%$ \\
\hline Partnerships & $43.6 \%$ & $28.5 \%$ & $36.0 \%$ \\
\hline Corruption_index & $0.51(0.16)$ & $0.52(0.15)$ & $0.52(0.16)$ \\
\hline Age_of_firms1 (after 2008) & 13.04 & 15.53 & 14.15 \\
\hline Age_of_firms2 (1999-2008) & 40.25 & 42.06 & 41.06 \\
\hline Age_of_firms3 (1992-1998) & 29.73 & 25.65 & 27.92 \\
\hline Age_of_firms4 (before 1992) & 16.97 & 16.75 & 16.87 \\
\hline Number of employees & $75.9(63.2)$ & $54.7(52.3)$ & $65.4(58.9)$ \\
\hline GRP_pc (2011, '000 rubles per person) & $255.2(160.3)$ & $242.2(141.1)$ & $251.2(153.1)$ \\
\hline Observations & 716 & 574 & 1290 \\
\hline
\end{tabular}


Table 3. Firm owners' assessment of satisfaction with the current scale of production (marginal effects)

\begin{tabular}{|c|c|c|c|}
\hline \multirow{2}{*}{ Variables } & \multicolumn{3}{|c|}{ Models } \\
\hline & $(1)$ & $(2)$ & (3) \\
\hline Deficit_qual_workers & $-0.0829^{*}(0.0443)$ & $-0.0928^{\star *}(0.0447)$ & $-0.0878^{\star}(0.0458)$ \\
\hline Margin_low & $-0.176^{\star *}(0.0480)$ & $-0.190^{* * *}(0.0490)$ & $-0.196^{* * *}(0.0492)$ \\
\hline External_finance & $-0.0738(0.0459)$ & $-0.0786^{\star}(0.0457)$ & $-0.0792^{\star}(0.0449)$ \\
\hline Old_equipment_share & $-0.002^{\star \star \star}(0.000479)$ & $-0.002^{* * \star}(0.000495)$ & $-0.002^{\star * *}(0.000501)$ \\
\hline Partnerships & $0.142^{\star \star}(0.0636)$ & $0.142^{* \star}(0.0641)$ & $0.142^{\star \star}(0.0657)$ \\
\hline Marketsize2 & $-0.0277(0.0380)$ & $-0.0231(0.0379)$ & $-0.0174(0.0375)$ \\
\hline Marketsize3 & $0.0913(0.0607)$ & $0.105^{\star}(0.0591)$ & $0.111^{*}(0.0585)$ \\
\hline Age2 (1999-2008) & $0.0845(0.0532)$ & $0.0940^{*}(0.0526)$ & $-0.214(0.166)$ \\
\hline Age3 (1992-1998) & $0.122^{\star *}(0.0520)$ & $0.124^{* *}(0.0511)$ & $-0.161(0.171)$ \\
\hline Age4(before 1992) & $0.0303(0.0710)$ & $-0.00194(0.0673)$ & $-0.412^{\star \star \star}(0.138)$ \\
\hline GRP_pc & & $2.63^{* * *}(0.923)$ & $2.67^{\star * *}(0.882)$ \\
\hline Corruption_index & & $-0.162(0.138)$ & $-0.723^{\star * \star}(0.258)$ \\
\hline Age $2^{*}$ Corruption_Index & & & $0.585^{\star}(0.310)$ \\
\hline Age $3{ }^{*}$ Corruption_index & & & $0.540^{*}(0.306)$ \\
\hline Age $4^{\star}$ Corruption_index & & & $0.918^{\star \star}(0.417)$ \\
\hline logNum_Employees & $0.102^{* * *}(0.0219)$ & $0.114^{* * *}(0.0232)$ & $0.114^{* * *}(0.0229)$ \\
\hline Pavitt_gr_2 & $-0.0600(0.0441)$ & $-0.0531(0.0431)$ & $-0.0554(0.0431)$ \\
\hline Pavitt_gr_3 & $-0.0998^{\star *}(0.0477)$ & $-0.123^{\star * *}(0.0441)$ & $-0.119^{* * *}(0.0429)$ \\
\hline Pavitt_gr_4 & $-0.0263(0.0804)$ & $-0.0203(0.0837)$ & $-0.0224(0.0851)$ \\
\hline Pseudo R2 & 0.0683 & 0.0792 & 0.0828 \\
\hline Observations & 1084 & 1057 & 1057 \\
\hline
\end{tabular}

The only "unexpected" result is the negative (though not very significant) impact of the use of bank credits. In other words, firms complaining about their scale of operations use bank loans more often than those who are satisfied with their businesses' performance. Two explanations for this result are probable. On the one hand, it may mean that firms dissatisfied with their scale use external financing extensively in order to increase the size of their businesses. On the other hand, this fact very probably reflects the specific situation in the Russian economy where interest rates, in particular those for SMEs, are relatively high and firms prefer not to take out loans if they can avoid it. Alas, our data does not allow us to confirm which interpretation is more valid. Nevertheless, the first hypothesis can be considered confirmed.

The second hypothesis concerning the inefficient scale of business being linked to demand side limitations was partially confirmed. Though we found no significant differences between firms trading inside their home region and those who trade inter-regionally, exports seem to have a positive impact on the probability of a firm considering their scale sufficient for successfully competing. In addition, the gross regional product per capita, which can be used as a proxy for higher demand, also has a substantial positive coefficient. The hypothesis about demand side factors also explains the significant negative coefficient for the sector of "specialized suppliers" because the market for such products usually is more notably limited, especially in the regions.

The most interesting results relate to the third hypothesis about the impact of the institutional environment on the probability of a firm reaching an optimal scale. As we mentioned earlier, we used a regional index for corruption as a proxy for the quality of the business climate and expected to find (as in other works) the negative impact of corruption on the probability of a firm to having an adequate scale of operations. The calculations in Model 2 confirmed this assumption, its size was statistically insignificant. We expected that the correlation between the level of corruption and the degree of satisfaction with one's scale of operations may depend on the age of the firm in question. Companies operating in an unfavorable institutional environment for a long time (and who have survived) very probably managed to adjust to the environment and have found the ways and means to use the deficiencies of the business climate to their benefit. If the above logic holds true, then younger firms must suffer the most. As our results (Model 3) demonstrate, we found empirical support for this statement. While on the average corruption increases the probability of complaints about scale, the combined effect of age and corruption for the firms established in the pretransition (Soviet) period is positive and statistically significant. In other words, former Soviet enterprises that survived the transition period are much more immune to corrupt environments compared to firms established after 2009. For firms established during the crisis of the 1990s and during the stage of economic growth (1999-2008), the impact of a harmful institutional environment is negative but significantly less so compared to the group of the relatively younger firms. 


\section{Conclusion}

Our research is an attempt to better understand the processes highlighted in the literature on entrepreneurship [Wright, Stigliani, 2012] that underlie entrepreneurial activity and growth in the specific institutional context of Russia.

In the era of the planned economy, large and highly concentrated enterprises dominated the manufacturing sector. One of the great structural shifts during the transition was the downsizing of those large companies and the creation of the SME sector. However, despite the 25 years of transition, the SME segment of Russian economy (in particular, manufacturing SMEs) is still underdeveloped compared to other countries. This can hardly be explained exclusively by the specific industrial structure of the economy or by pathdependence. Nevertheless, the fact remains that among the seven EU countries, the only transitioning economy, Hungary, had the highest ratio of SME managers dissatisfied with the scale of operations, which indicates that the transition may be partly responsible. However, the stagnation in the development of SMEs in Russia demonstrates that the problems cannot be explained by an unfinished transition alone.

In a comparison of the statistics collected during the large-scale business survey for the seven EU countries and for Russia, we show that there are a distinct differences in the share of SMEs in the manufacturing sector that consider their scale of operations sufficient for competing on the market. Approximately half of the manufacturing SMEs in Russia would like to increase their operations compared with less than $15 \%$ in EU countries. However, in terms of employment, Russian SMEs are comparable to their European counterparts though they lag behind in terms of turnover. In this paper, we have attempted to investigate the reasons why Russian SMEs are so dissatisfied with the scale of their operations. Or, more precisely, what is the difference between the firms complaining about their scale of activity and those who manage to reach an adequate scale of production? We presumed that a firm's inability to grow to an optimal scale may be due to the three groups of factors. These include those on the supply side, a lack of access to the resources necessary for growth, those on the demand side, the small size of the market and an inability to overcome this limitation by entering broader markets (due to the high transaction costs), and, finally, the unfavorable business environment that prevents the growth of small and medium businesses.

Our findings partially correspond to the previous empirical literature on developing and transitional economies. Our overall results indicate that "good" firms in terms of performance and resources (such as access to qualified labor, new equipment, business networks, etc.) have more chances to reach an adequate scale. We found also that the size of the market upon which firms are selling their products also matters: access to export markets increases the probability of a firm being satisfied with their scale of business by $10 \%$. In addition, a location in more prosperous regions (regions with a higher gross regional product per capita) also has a positive impact on a manager's satisfaction with the scale of production.

Some new, interesting results of the paper are related to the impact of the institutional environment on firms' satisfaction with their production scale. Using the regional corruption index as a proxy for the quality of the institutional environment, we found that a corrupt environment has a negative impact on the perception of adequate scale. However, this effect depends upon the generation to which firms belong. It is extremely negative for the relatively young firms that are less than five years old, especially compared to the old former Soviet enterprises. Our findings demonstrate that SMEs that have managed to survive in an unfavorable environment for some time eventually adjusted to some extent to the existing business climate. It might be posited that only those firms that manage to learn how to bargain with inefficient institutions have a chance of survival (and help this system become self-sustaining). This may be one of the reasons why there are so few SMEs in the Russian manufacturing sector compared to other countries and the reason why so few of them are able to successfully compete on foreign markets. The unfavorable environment may be one of the reasons why Russian firms are so dissatisfied with their current scale: high bureaucratic barriers and transaction costs make smaller firms more vulnerable to administrative pressure. Therefore, a firm in Russia must be larger than its counterpart in a developed economy to survive and remain on the market.

The study was implemented in the framework of the Basic Research Program at the National Research University Higher School of Economics (HSE) in 2015-2017.

\section{References}

Acs Z., Audretch D. (2001) The Emergency of the Entrepreneurial Society. Paper presented at the International Award for Entrepreneurship and Small Business research, 3 May, 2001, Stockholm.

Acs Z., Armington C. (2004) Employment growth and entrepreneurial activity in cities. Regional Studies, vol. 38, no 8, pp. 911-927.

Aidis R. (2015) Is Russia an entrepreneurial society? Challenges for Russia’s Politicized Economic System (ed. Susanne Oxentierna), New York: Routledge, pp. 77-95.

Aidis R., Estrin S., Mickiewicz T. (2008) Institutions and entrepreneurship development in Russia: A comparative perspective. Journal of Business Venturing, vol. 23, no 6, pp. 656-672.

Aghion P., Howitt P. (1997) Endogenous Growth Theory, Cambridge, MA: MIT Press.

Autio E., George G., Alexy A. (2011) International Entrepreneurship and Capability Development - Qualitative Evidence and Future Research Directions. Entrepreneurship: Theory and Practice, vol. 35, no 1, pp. 11-37. 
Ahrend R. (2006) Russian industrial restructuring: Trends in productivity, competitiveness and comparative advantage. Post-Communist Economies, vol. 18, no 3, pp. 277-295.

Bartelsman E., Haltiwanger J., Scarpetta S. (2013) Cross-country differences in productivity: The role of allocation and selection. The American Economic Review, vol. 103, pp. 305-334.

Bennet V., Levinthal D. (2017) Firm lifecycles: Linking employee incentives and firm growth dynamics. Strategic Management Journal. DOI 10.1002/smj.2644.

Bhaumik S.K., Estrin S. (2007) How transition paths differ: Enterprise performance in Russia and China. Journal of Development Economics, vol. 82, no 2, pp. 374-392.

Blagojevic S., Damijan J.P. (2013) The imact of corruption and ownership on the performance of firms in Central and Eastern Europe. Post-Communist Economies, vol. 25, no 2, pp. 133-158.

Bruno R.L., Bytchkova M., Estrin S. (2008) Institutional determinants of new firm entry in Russia: A cross regional analysis (Quaderni - Working Paper DSE no 650). Available at: https://www.econstor.eu/bitstream/10419/159491/1/ wp0650.pdf, accessed 24.06.2017.

Chepurenko A. (2012) Chto takoe predprinimatel'stvo I kakaya politika v otnoshenii predprinimatel'stva nuzhna $\mathrm{v}$ Rossii (Zametki na polyakh rabot zarubezhnykh klassikov) [What is entrepreneurship and what political approach to entrepreneurship does Russia need? (Marginal Notes on Works of Modern Foreign Classics)]. Zhurnal Novoi Ekonomicheskoi Assotsiatsii [Journal of the New Economic Association], vol. 14, no 2, pp. 102-124 (in Russian).

Chepurenko A. (2015) Entrepreneurial activity under "transition". Context, Process and Gender Entrepreneurship: Frontiers in European Entrepreneurship Research (eds. R. Blackburn, U. Hytti, F. Welter), Cheltenham: Edward Elgar, pp. 6-22.

Cuaresma J.C., Oberhofer H., Andronova Vincelette G. (2013) Firm growth and productivity in Belarus: New empirical evidence from the machine building industry. Journal of Comparative Economics, vol. 42, no 3, pp. 726738.

Dallago B. (2000) The Organizational and Productive Impact of the Economic System: The Case of SMEs. Small Business Economics, vol. 15, no 4, pp. 303-319.

Djankov S. (1999) The restructuring of insider-dominated firms: A comparative analysis. Economics of Transition, vol. 7, no 20, pp. 467-479.

EBRD (2013) The Business Environment and Enterprise Performance Survey. The Russian Regions: Results, London: European Bank for Reconstruction and Development. Available at: http://www.ebrd.com/downloads/research/ factsheets/beeps.pdf, accessed 17.04.2017.

Ericson R., Pakes A. (1995) Markov-perfect industry dynamics: A framework for empirical research. Review of Economic Studies, vol. 62, no 1, pp. 53-82.

Estrin S., Bevan A., Kuznetsov B., Schaffer M., Angelucci M., Fennema J., Mangiarotti G. (2001) The Determinants of Privatised Enterprise Performance in Russia (William Davidson Institute Working Papers Series 452), Ann Arbor, MI: University of Michigan.

Estrin S., Meyer K., Bytchkova M. (2006) Entrepreneuship in transition economies. The Oxford Handbook of Entrepreneurship (eds. M. Casson, B. Yeung, A. Basu, N. Wadeson), Oxford: Oxford University Press, pp. 693-725.

Estrin S., Korosteleva J., Mickiewicz T. (2013) Which institutions encourage entrepreneurial growth aspirations? Journal of Business Venturing, vol. 28, pp. 564-580.

Filatotchev I., Buck T., Zhukov V. (2000) Downsizing in privatized firms in Russia, Ukraine, and Belarus. Academy of Management Journal, vol. 43, no 3, pp. 286-304.

Foster L., Haltiwanger J., Syverson C. (2012) The slow growth of new plants: Learning about demand? (NBER Working Paper 17853), Cambridge, MA: National Bureau of Economic Research.

Golikova V., Ermilova G. (2006) Competitiveness of Small Enterprises: Evidence from Empirical Survey in Two Russian Regions. Institute of Economic Research Discussion Paper Series B, no 34: New Generation of Russian Economic Studies, Tokyo: Hitotsubashi University, pp. 39-64.

González A., Leonardo I., Hari S. (2013) Russian volatility: Obstacle to firm survival and diversification (Policy Research Working Paper WPS 605), Washington, DC: World Bank.

Geurts K., van Biesebroek J. (2016) Firm creation and post-entry dynamics of de novo entrants. International Journal of Industrial Organization, vol. 49(C), pp. 59-104.

Hermans J., Vanderstraeten J., Dejardin M., Ramdani D., Stam E., van Witteloostuijn A. (2012) Ambitious entrepreneurship: Antecedents and consequences (Research Paper 2012-023), Antwerpen: University of Antwerpen.

Hessels J., Parker S.C (2013) Constraints, Internationalization and Growth: A Cross-Country Analysis of European SMEs. Journal of World Business, vol. 48, no 1, pp. 137-148.

Hsieh C.T., Klenow P. (2009) Misallocation and Manufacturing TFP in China and India. The Quarterly Journal of Economics, vol. 124, no 4, pp. 1403-1448.

Hoskisson R.E., Eden L., Lau C.M., Wright M. (2000) Strategy in emerging economies. Academy of Management Journal, vol. 43, no 3, pp. 249-267.

Hoskisson R., Covin J., Volberda H., Johnson R. (2011) Revitalizing entrepreneurship: The search for new research opportunities. Journal of Management Studies, vol. 48, no 6, pp. 1141-1168.

MED, FOM (2011) Sostoyanie bytovoi korruptsii v Rossiiskoi Federatsii [State of the everyday corruption in the Russian Federation], Moscow: Ministerstvo ekonomicheskogo razvitiya Rossiiskoi Federatsii [Ministry of Economic Development of the Russian Federation], Fond "Obshchestvennoye Mneniye" [Public Opinion Foundation]. Available at: http://www.indem.ru/corrupt/doklad_cor_INDEM_FOM_2010.pdf (in Russian).

Iwasaki I., Maurel M., Meunier B. (2016) Firm entry and exit during a crisis period: Evidence from Russian regions. Russian Journal of Economics, vol. 2, no 2, pp. 162-191.

Jovanovic B. (1982) Selection and Evolution of Industry. Econometrica, vol. 50, no 3, pp. 25-43.

Kolvereid L. (1992) Growth aspirations among Norwegian entrepreneurs. Journal of Business Venturing, vol. 7, no 3, pp. 209-222.

Krasniki B., Desai S. (2016) Institutional drivers of high-growth firms: Country-level evidence from 26 transition economies. Small Business Economics, vol. 47, no 4, pp. 1075-1094.

Lee N. (2014) What holds back high-growth firms? Evidence from UK SMEs. Small Business Economics, vol. 43, no 1, pp. 183-195.

Linz S.J., Krueger G. (1998) Enterprise restructuring in Russia's transition economy: Formal and informal mechanisms. Comparative Economic Studies, vol. 40, no 2, pp. 5-52.

Manev I., Manolova T. (2010) Entrepreneurship in transition economies: Review and intergration of two decades of research. Journal of Developmental Entrepreneurship, vol. 15, no 1, pp. 69-99.

Marcelin I., Mathur I. (2015) Privatization, Financial Development, Property Rights and Growth. Journal of Banking and Finance, vol. 50 (C), pp. 528-546. 
Mason C., Brown R. (2013) Creating good public policy to support high-growth firms. Small Business Economics, vol. 40, no 2, pp. 211-225.

Melitz M.J. (2003) The Impact of Trade on Intra-Industry Reallocations and Aggregate Industry Productivity. Econometrica, vol. 71, no 6, pp. 1695-1725.

Meyer K., Peng M. (2005) Probing theoretically into Central and Eastern Europe: Transactions, resources, and institutions. Journal of International Business Studies, vol. 36, no 6, pp. 600-621.

Meyer K., Peng M. (2016) Theoretical foundations of emerging economy business research. Journal of International Business Studies, vol. 47, no 1, pp. 3-22.

Mohr V., Garnsey E., Theyely G. (2014) The role of alliences in the early development of high-growth firms. Industrial and Corporate Change, vol. 23, no 1, pp. 233-259.

Molz R., Tabbaa I., Totskaya N. (2009) Institutional Realities and Constraints on Change: The Case of SME in Russia. Journal of East-West Business, vol. 15, no 2, pp. 141-156.

Navaretti G.B., Castellani D., Pieri F. (2014) Age and firm growth: Evidence from three European countries. Small Business Economics, vol. 43, no 4, pp. 823-837.

Navaretti G.B., Altomonte C., Bugamelli M., Schivardi F., Horgos D., Maggioni D. (2010) The Global Operations of European Firms (Second EFIGE Policy Report, BREUGEL, Nov' 10), Brussels: BRUEGEL. Available at: http:// bruegel.org/wp-content/uploads/imported/publications/efige_II_ws_14711.pdf, accessed 12.04.2017.

OECD (2015) Russian Federation: Key Issues and Policies. OECD Studies on SMEs and Entrepreneurship, Paris: OECD.

OPORA (2016) Antikrizisnyi monitoring OPORY ROSSII [OPORA's Anti-crisis monitoring], Moscow: OPORA. Available at: http://www.opora.ru/upload/iblock/f53/f53f9e8a614f68632850d774edef8b6f.pdf (in Russian).

Ojala A., Isomaki H. (2011) Entrepreneurship and small business in Russia: A review of empirical research. Journal of Small Business and Enterprise Development, vol. 18, no 1, pp. 97-119.

Pakes A., Ericson R. (1998) Empirical implications of alternative models of firm dynamics. Journal of Economic Theory, vol. 70, no 1, pp. 1-45.

Pavitt K. (1984) Sectoral patterns of technical change: Towards a taxonomy and a theory. Research Policy, vol. 13, pp. 343-373.

Peng M.W. (2001) How entrepreneurs create value in transition economies. Academy of Management Executive, vol. 15, no 1, pp. 95-108.

Ployhart R., Moliterno T. (2011) Emergence of human capital resource: Multilevel approach. Academy of Management Review, vol. 36, no 1, pp. 127-150.

Puffer S.M., McCarthy D.J., Boisot M. (2010) Entrepreneuship in Russia and China: The impact of formal institutional voids. Entrepreneurship Theory and Practice, vol. 34, no 3, pp. 441-467.

Rajan R., Zingales L. (1998) Financial Dependence and Growth. American Economic Review, vol. 88, no 3, pp. 559586.

Rice J., Liao T.-S., Martin N., Galvin P. (2012) The role of strategic alliances in complementing firm capabilities. Journal of Management and Organization, vol. 18, no 6, pp. 859-869.

Richter A., Schaffer M.E. (1996) The Performance of De Novo Private Firms in Russian Manufacturing (CERT Discussion Paper no 9610), Edinburgh: Center for Economic Reform and Transformation.

Rosstat (2014) Maloe i srednee predprinimatel'stvo v Rossii [Small and medium entrepreneurship in Russia], Moscow: Rosstat. Available at: http://www.gks.ru/free_doc/doc_2014/mal-pred-all.rar, accessed 17.03.2016 (in Russian).

Sharafutdinova G., Kisunko G. (2014) Governors and Governing Institutions: A Comparative Study of State-Business Relations in Russia's Regions (Policy Research Working Paper WPS 7038) Washington, D.C.: World Bank, Governance Global Practice Group.

Smallbone D., Welter F. (2010) Enterpreneurship and the Role of Government in Post-Socialist Economies: Some Institutional Challenges. Historical Social Research, vol. 35, no 2, pp. 320-333.

Smallbone D., Welter F., Ateljevic J. (2014) Entrepreneurship in emerging market economies: Contemporary issues and perspectives. International Small Business Journal, vol. 32, no 2, pp. 113-116.

Song Z., Storesletten K., Zilibotti F. (2011) Growing like China. The American Economic Review, vol. 101, no 1, pp. 196-233.

Stenholm P., Toivonen J. (2009) The attributes of firm growth - Why and why not a firm does grow. Frontiers of Entrepreneurship Research, vol. 29, no 13, article 4. Available at: http://digitalknowledge.babson.edu/cgi/ viewcontent.cgi? article $=1590 \&$ context $=$ fer, accessed 25.04.2016.

Street C.T., Cameron A.-F. (2007) External Relationships and the Small Business: A Review of Small Business Alliance and Network Research. Journal of Small Business Management, vol. 45, no 2, pp. 239-266.

Thorsten B., Demirgüç-Kunt A. S. L. I., Maksimovic V. (2005) Financial and legal constraints to growth: Does firm size matter? The Journal of Finance, vol. 60, no 1, pp. 137-177.

Tybout J. (2000) Manufacturing Firms in Developing Countries: How Well Do They Do, and Why? Journal of Economic Literature, vol. 38, no 1, pp. 11-44.

Volchek D., Henttonen K., Edelmann J. (2013a) Exploring the Role of a Country's Institutional Environment in Internationalization: Strategic Responses of SMEs in Russia. Journal of East-West Business, vol. 19, no 4, pp. $317-$ 350.

Volchek D., Jantunen A., Saarenketo S. (2013b) The institutional environment for international entrepreneurship in Russia: Reflections on growth decisions and performance in SMEs. Journal of International Entrepreneurship, vol. 11, no 4, pp. 320-350.

Wang Yu., You J. (2012) Corruption and firm growth: Evidence from China. China Economic Review, vol. 23, no 2, pp. $415-433$.

Weber P., Geneste L.A., Connell J. (2015) Small business growth: Strategic goals and owners' preparedness. Journal of Business Strategy, vol. 36, no 3, pp. 30-36.

Welter F., Smallbone D. (2011) Institutional Perspectives on Entrepreneurial Behavior in Challenging Environments. Journal of Small Business Management, vol. 49, no 1, pp. 107-125.

Wright M., Stigliani I. (2012) Entrepreneurship and growth. International Small Business Journal, vol. 31, no 1, pp. 3-22.

Yakovlev E., Zhuravskaya E. (2007) Deregulation of Business (CEPR Discussion Paper no 6610), London: Centre for Economic Policy Research.

Yukhanaev A., Fallon G., Baranchenko Y., Anisimova A. (2015) An Investigation into the formal institutional constraints that restrict entrepreneurship and SME growth in Russia. Journal of East-West Business, vol. 21, no 4, pp. 313-341. 